\title{
SWALLOWING DISORDERS AFTER HEMIGLOSSECTOMY
}

By

Kenjiro YaNAGiNO, Masaro HigUCHI, SANetomi EGUCHI

From the Department of Oto-Rhino-Laryngology, Medical Faculty, University of Nagasaki (Director: Prof. T. Goto)

Authors observed swallowing in II cases, (by cinefluorography) who were hemiglossectomized in lingual cancer.

Swallowing disorders in these cases were caused by the insufficient of glossopalatinal closure due to lack of the half of the tongue and the injuries of neck muscle due to radical neck dissection.

But we could not find the remarkable differe- nces in the swallowing after hemiglossectomy between total hemiglossectomized cases and the cases where the root remained because the compensatory movement of the rest half of the tongue.

These observations led us to believe that in surgery of lingual cancer thorough total hemiglossectomy including the root of the tongue must be performed.

\section{舌 半 側 切 除と曣下機 能}

\section{長崎大学医学部耳鬼咽堠科学教室 (主任：後藤敏郎教授)

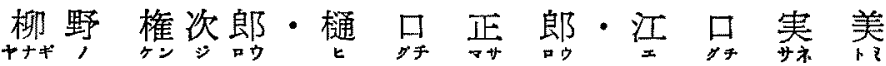

\section{緒 言}

舌癌の手術的治療に対する最も大きな担抗は涌後の機

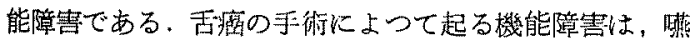
下機能と言語に関するものであるが、これらの隌㿡につ いて観察されたものは㫊んど見られない，最近の医学の リヘビリテーションへの闒心と〉もにこの問題む研究 の必要が感ぜられる，著者らの教䇪では舌癌は原則とし て舌半例切除と頸部廓清術を行らことにしているが，こ れら50列飞就ての臨床的及び病理組織学的の钼察につ いては，さきに報告したところであるが，著者らはこれ

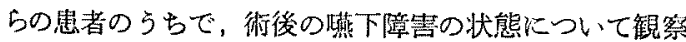
し得た 11 例に就ての成續を報告する。

\section{症例}

检查を行つた症例は，1952年1月からら1961年6月ま での間に長崎大学耳舆咽喉科において，舌半側切除をう けたもの」ららで生存を確認することができ，検査に応 した11例である，症例の選択は，全く at randomに 行なわれた訳けであつて，内訳けは，男子9侧，女子 2 例で, 年令は 37 才から63才までのるのであつて，若年 诸は1例が友られた，術後の絽過年数は1力月のものか ら10年を経過したものにまでわたつている，又，辞根
を含めて舌半側切除を行つたものは4例，舌根を残した ものは7例であつた（表1）。

\section{観祭方法}

榆查は X 線テレビ泟置心より，患者を起立させて透 視を行い，前後方向と左右方向よりその影像を $16 \mathrm{~mm}$ 映画に撮影した．観察は症例を舌根の有與によつて2 群 に分かつて観察した。

表 1

\begin{tabular}{|c|c|c|c|c|c|}
\hline No. & 症 例 & 性 & 年令 & 術後年数 & 舌根 \\
\hline 1 & T. $\mathrm{S}$ & $\delta$ & 46 & y $1 \mathrm{~m}$ & 有 \\
\hline 2 & K. G & 3 & 59 & $3 \geqslant 8 \%$ & " \\
\hline 3 & K. $\mathrm{M}$ & 今 & 53 & $3 \geqslant 1 \%$ & 無 \\
\hline 4 & Y. A & ㅇ & 47 & $44 \%$ & 有 \\
\hline 5 & K. $\mathrm{K}$ & ㅇ & 54 & $1 \geqslant 2 \%$ & " \\
\hline 6 & U. $\mathrm{N}$ & 3 & 52 & $5 " 3 \%$ & " \\
\hline 7 & N. $\mathrm{H}$ & $\delta$ & 63 & $10 \% 0 \%$ & 無 \\
\hline 8 & K. J & $\delta$ & 56 & $" 1 "$ & " \\
\hline 9 & M. S & $\hat{\delta}$ & 44 & " 1 " & 有 \\
\hline 10 & N. $\mathrm{M}$ & 当 & 37 & $" 1 "$ & 無 \\
\hline 11 & M. A & $\hat{\delta}$ & 57 & $" 1 "$ & 有 \\
\hline
\end{tabular}




\section{観察結果}

口控内の状態は側面像では著明な暃常所見がみられな いのは当然であるが, 前媵方向において, バリウムの旡 影が舌の両側に及ぶものと, 切除欠損側にのみ偏在する ものとが観察された．各症例について術後年数及び肉眼 的所見と比較検討してみると，パリウムの陰影が舌の両 側に及ぶものは 5 例で, 術後年数が長いものに多く，欠 損側にのみ偏在するものは6 例で, 術後年数が短いもの に多く見られた。前者は健側の舌が中央へ移動したる ので,このために両側の煩部粘膜との間にハシリムの停 滞が起ることを示している. 術後年数が経るとともに， 残存半側舌は幅の狭い丸味を帯びた型に変り, 切除側の 軟口蓋に索引されて，口蓋舌被壁に似た粘膜被壁ができ て, 残存舌を健側へ索引することになり正中位に移動与 る汇至る（表 2, 図 1，2，3）.

咽頭に㧍けるバリウム影像の状態は，嬩下運動が起る 以前から既に口腔内より少量梨状楩凹部に流下眝留して

表 2

\begin{tabular}{|c|c|c|c|}
\hline No. & 術 後年 数 & ロ腔内の状態 & 台恨 \\
\hline 1 & 1 力月 & 両 側に存 在 & 有 \\
\hline 2 & 3年 8力月 & " & " \\
\hline 3 & 3年 1力月 & " & 無 \\
\hline 4 & 4 力月 & 片側のみに存在 & 有 \\
\hline 5 & 1年 2力月 & " & " \\
\hline 6 & 5年 3力月 & 両 側に存 在 & " \\
\hline 7 & 10年 0力月 & 片側のみに存在 & 無 \\
\hline 8 & 1 カ月 & 両 側に存 在 & " \\
\hline 9 & 1カ月 & 片側のみに存在 & 有 \\
\hline 10 & 1 カ月 & " & 無 \\
\hline 11 & lカ月 & " & 有 \\
\hline
\end{tabular}

図 1 パリウム影像は舌の両側に分る

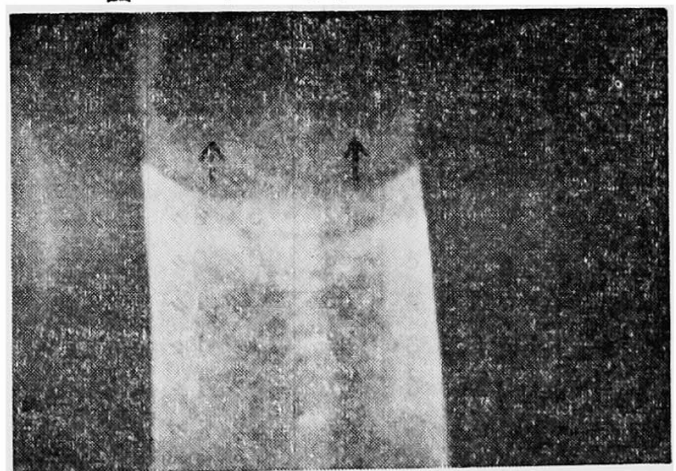

図 2 舌の片侧（切除側）にのみ陰影あり

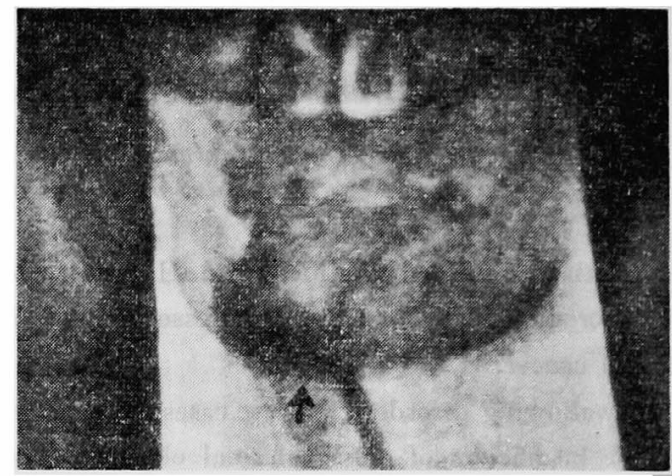

図 3 正中移動した残存舌

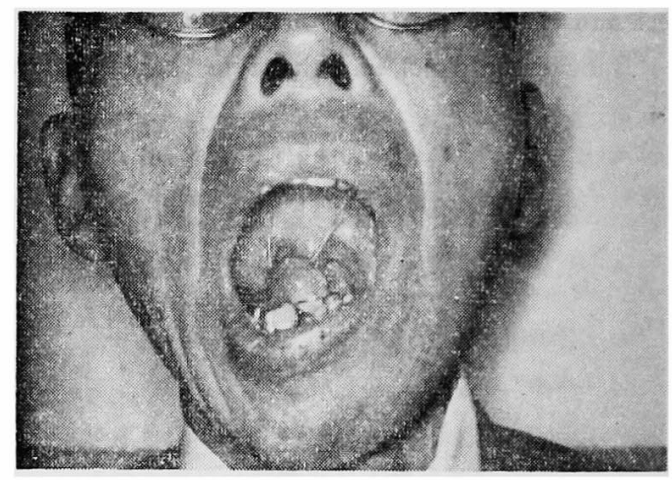

いるいるものもある．あるいは更に咽頭を経て食道へ流 入するものも見られた。これらの状態は，舌が代償的に 正中位に移動をした例に多く見られた。

食道入口部では，鮰下運動によつて咽頭へ送られたバ リウムは，正常例に和ける嚥下と全く同様な状態が認め られたものは1例のみで，他の 10 例は上述の!ような障 害が見られ，その約半数は喉頭口の閉鎖が不完全なため に, バリウムの気管内へ少量づつ流入するのが認められ

図 4 燕下洔にパリウムは一部気管内に流入

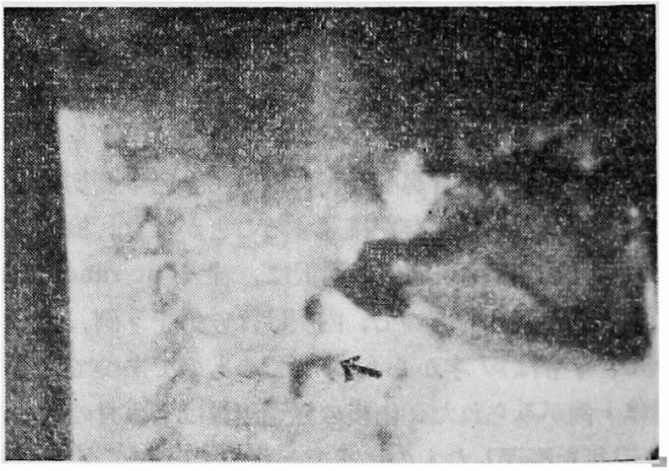


た。艺の都度咳濑が迎り，バリウムを啹頭外に呼出し，

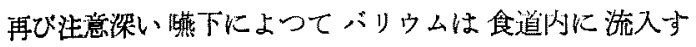
る。呢頭口の閉鎖不全の大きな湶因は年根後退による被

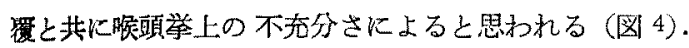

\section{考按}

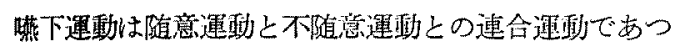
て，横紋䈌と平咀筋とが近接する部位で行なわれる。神 絴支配は平滑笳は Auerbach 氏神経緗胞，口堅咽頭は

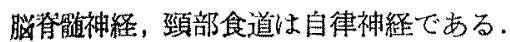

口腔内人食塊が入ると，M. mylohyoideus が収称し

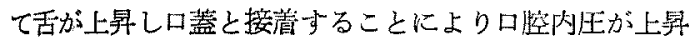

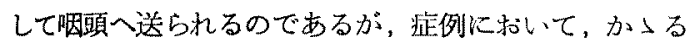
顝意運動に障察がみられたのは，舌が半側のみであるた めに口空内代を上景するに不充分であること〉，吉口盖 閉鎖機能障害をきたしていること，及び莖頁部咸清術時に 関連朌肉を障㕩したために起つたと考えるられ。

食塊が咽頭へ入つてくると，M. levator veli palatini, M. tensor veli palatini の収縮之 Passervant 氏隆起

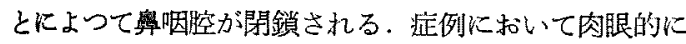
軟口蓋の舌正中移動に伴与前方移動が見られたにもか子 わらず，番腔への蒥下時逆流が観察されないのは，この 閉鋇機能は正常と思方れる。

食塊の下咽頭通過に際しては，M. Geniohyoideus, M. mylohyoideusによる舌骨の前方移動, M. styloglos. sus の繁涱による舌根の後退，M. thyreohyoideus の

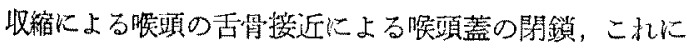
流〈M. constrictor pharyngis media, inferior D收縮 に上る咽頭王上年の絬果，食道入口部が開大して通過与

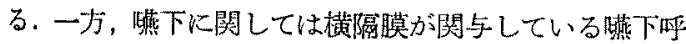

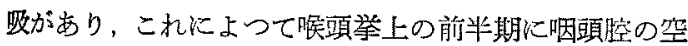
気志吸引して Aerophagie を防止し，後半期より下降 期にかけては声閒が閶大しないららから呼息が迅つて器

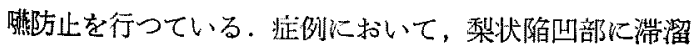
すること，友管へ少量づつ流入すること，及び食道入口

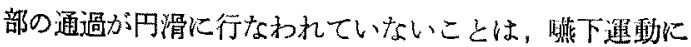

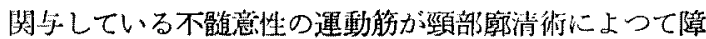

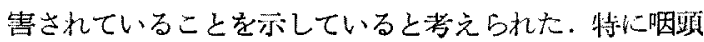
の挙上と古の後退とに関係ある觔辟 (M. styloglossus, M. stylohyoideus, M. digastricus 等) の障害に大き な理由があると洘えられる。

以上の考按を舌根の有然によつて分つだ 2 群について みると，2样の間に诸しい差異が見られなかつた。

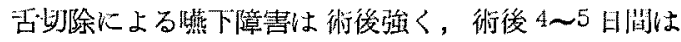

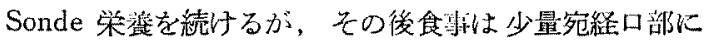

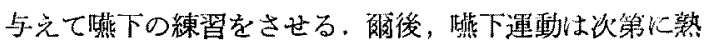
練してくるものである。但し例によつては 2 週〜3週の 長期に亘つて強い與下困難を訴えたために Sonde 栄盖 を続けなけ机ばならない例るあつたが，著者らの経験例

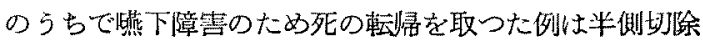
例では1例であつた，斯る例は嫄頭全摘出を行うことが 必學である。しかし一般には上述の程度の障害に抋いて

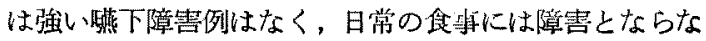
いことを知つた。

\section{文献}

1)㕕戸：食道狄察の部位とその生理，気食報，7： 1，1956. 2）広戸：食道知覚の不蜆則性，気食報， 5: 105, 1954. 3) 甲田：與下及び食道運動に関与る

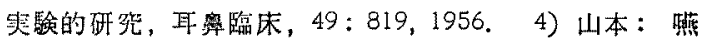
下之呼吸上の関倸に関する実験的研究, 耳鼻臨床, 49:

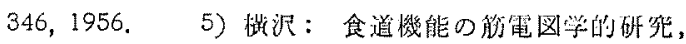

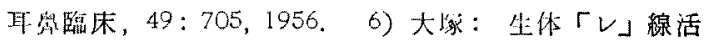

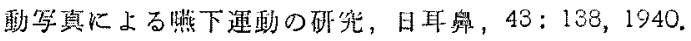

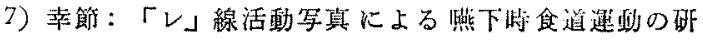
究，日本外会誌，40：1894，1939。8）後藤(敏)：耳

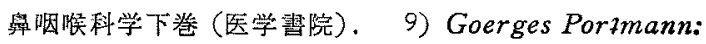
Diseases of the Ear, Nose and Throat, 1951 年. 10) Pack and Ariel: Treatment of Cancer and Allied Diseases, Second Edition.

（原閭到着=昭和 37.12 .23 日） 